\title{
Phytoplankton release of extracellular organic carbon, molecular weight composition, and bacterial assimilation
}

\author{
Lars Møller Jensen
}

Botanical Institute, University of Aarhus, Nordlandsvej 68, DK-8240 Risskov, Denmark

\begin{abstract}
Phytoplankton release of extracellular dissolved organic carbon (EOC) and its subsequent assimilation by planktonic bacteria was quantified using the procaryotic inhibitor streptomycin. The carbon flow was assayed in the Danish estuary, Randers Fjord, and in laboratory experiments. From 34 to $90 \%$ of the released carbon was transported to the bacteria; the bacterial metabolism of EOC ranged from 3 to $30 \%$ of total primary production. If no correction for bacterial respiration $(20$ to $50 \%)$ is made the EOC transport can be seriously underestimated. The released products were predominantly of low molecular weight (<900 Daltons). The bacteria showed distinct selectivity for these small molecules. Streptomycin, an active bactericidal agent, also affected algal photosynthesis in some cases. In carbon flow experiments antibiotics must be used with great care.
\end{abstract}

\section{INTRODUCTION}

It is well documented that phytoplankton release extracellular organic carbon (EOC) which serves as energy source for microheterotrophic organisms (Nalewajko, 1977; Smith et al., 1977; Larsson and Hagström, 1979, 1982; Iturriaga, 1981; Riemann et al., 1982). EOC is converted to particulate organic carbon (POC) which can be used as a food source at higher trophic levels (Nalewajko, 1977; Riemann et al., 1982; Riemann and Sondergaard, in press).

Principally, 2 methods have been used to measure the transfer of EOC between phytoplankton and bacteria: a differential filtration technique (e.g. Derenbach and Williams, 1974; Larsson and Hagström, 1979, 1982; Coveney, 1982) and a method involving the addition of a ${ }^{14} \mathrm{C}$ pre-labeled EOC solution to a sample (Herbland, 1975; Iturriaga and Hoppe, 1977; Wiebe and Smith, 1977; Bell and Sakshaug, 1980). The differential filtration technique is relatively simple and thus suitable for in situ experiments. However, because plankton populations are not always amenable to size-fractionation the method cannot be used uncritically. Addition of a ${ }^{14} \mathrm{C}$-EOC solution to a sample has 2 advantages in preference to the fractionation technique: knowledge about the composition and size-

(c) Inter-Research/Printed in F. R. Germany distribution of the plankton is not required and by measuring the evolution of ${ }^{14} \mathrm{C}-\mathrm{CO}_{2}$ the mineralization of the added ${ }^{14} \mathrm{C}$-EOC products can be calculated. The method involves several manipulations of the sample making the method unpractical at in situ experiments.

In order to evaluate the ecological significance of EOC it is necessary to know the gross release of EOC. Because the algal release and bacterial assimilation of EOC takes place simultaneously the EOC release will be underestimated (Nalewajko, 1977). As a consequence the methods mentioned measure the net or apparent release and transport of EOC. These problems are especially significant if a ${ }^{14} \mathrm{C}$-EOC preparation is used because a fraction of the labile products is assimilated and transformed by the bacteria during the incubation, thus changing the assimilation kinetics of the released EOC products.

If the bacterial activity can be eliminated it is possible to estimate the gross release. The use of antibiotics have been applied with varying success (Anderson and Zeutchel, 1970; Derenbach and Williams, 1974; Berman, 1975; Iturriaga and Hoppe, 1977; Chrost, 1978; Schleyer, 1981).

The purpose of the present study was to quantify the gross release of extracellular organic carbon by phytoplankton and the subsequent assimilation and trans- 
formation of these products by the surrounding bacterial flora. Streptomycin was used as a specific procaryotic inhibitor.

\section{MATERIALS AND METHODS}

Water samples were collected in the estuary Randers Fjord, Denmark. During sampling the salinity ranged from 2 to $6 \% \mathrm{~S}$.

\section{Laboratory experiments}

Surface water samples were collected with a sterilized bottle and transported to the laboratory at in situ temperature within $2 \mathrm{~h}$.

Homogeneous subsamples were dispensed into $25 \mathrm{ml}$ Jena glass bottles. The specific procaryotic inhibitor streptomycin (SM) was added to one bottle series (25 to $30 \mu \mathrm{g} \mathrm{ml}^{-1}$ ) to inhibit the physiological activity and growth of the bacterial population. At this concentration of SM the bacterial assimilation of ${ }^{14} \mathrm{C}$ glucose was depressed over $90 \%$ while no effect on algal photoassimilation could be demonstrated.

After a pre-incubation of $1 \mathrm{~h}$ at in situ temperature $\left( \pm 1 \mathrm{C}^{\circ}\right)$ and a light intensity of $200 \mu \mathrm{EM}^{-2} \mathrm{~S}^{-1}, 2 \mu \mathrm{Ci}$ ${ }^{14} \mathrm{C}_{-} \mathrm{HCO}_{\overline{3}}$ was added to each bottle.

A sample from each series, filtered immediately after tracer addition, served as time zero blank (Morris et al., 1971). Blank values are substracted from results. After incubation, $20 \mathrm{ml}$ from each sample was filtered $(0.2 \mu \mathrm{m}$ Sartorius membranes) under vacuum $(<200 \mathrm{mmHg})$. The filters were rinsed with $5 \mathrm{ml}$ filtered (Whatman GF/C) water from the sampling locality, placed in $4 \mathrm{ml}$ polyethylene scintillation vials and exposed to fumes of formaldehyde and $\mathrm{HCl}$ to stop biological activity and remove any residual inorganic ${ }^{14} \mathrm{C}$.

The measurement of labeled EOC in the filtrates followed Søndergaard (1980). Radioactivity was assayed by liquid scintillation counting (Intertechnique SL 30). Quench correction was made by the external standard method. The results obtained gave $\mathrm{CV}$ values of 2 to $8 \%$ (mean $5 \%$ ) and 2 to $10 \%$ (mean $5 \%$ ) for filters and filtrates, respectively.

\section{In situ experiments}

The in situ experiments were carried out during the senescence of a spring diatom bloom. Water samples from the surface, $1 \mathrm{~m}$ depth and in the immediate vicinity of the bottom (approximately $2 \mathrm{~m}$ ) were collected in sterilized bottles.

Cumulative short time incubations of 2 or $3 \mathrm{~h}$ duration were used to follow the diel pattern of carbon flow.
SM was added to half the samples as previously described. After incubation the samples were filtered within $10 \mathrm{~min}$. The samples were protected against direct sunlight before and after the incubation. Sample preparation in the field followed the procedure described for laboratory experiments.

\section{Molecular weight distribution of released EOC products}

The molecular weight distribution of the released EOC products was measured with gel-chromatography (Sephadex, Pharmacia Corp.). Samples for gelchromatography were incubated parallel with other samples. A ${ }^{14} \mathrm{C}$-activity of $5 \mu \mathrm{Ci} 25 \mathrm{ml}^{-1}$ was used.

After incubation the samples (50 to $100 \mathrm{ml}$ ) were filtered (0.2 $\mu \mathrm{m}$ Sartorius membranes), acidified to $\mathrm{pH}$ $2.8(1 \mathrm{~N} \mathrm{HCl})$ and purged with air for $40 \mathrm{~min}$. The filtrates stripped for inorganic ${ }^{14} \mathrm{C}$ were concentrated $20 \times$ on a rotary evaporator at $30^{\circ} \mathrm{C}$ and fractionated on a Sephadex G-50 column $(38 \times 2.6 \mathrm{~cm}$, fine grade $)$ with a dextran exclusion limit of 10000 Daltons.

The concentrated samples were eluted and assayed for activity according to Søndergaard (1981).

\section{Calculations}

Carbon fixation was calculated as described by Gargas (1975). To calculate the bacterial assimilation and incorporation of EOC into bacterial biomass the following equations were used:

$$
\begin{aligned}
& \text { (1) } A=A^{\prime}+B+B R \\
& \text { (2) } P=P^{\prime}-B
\end{aligned}
$$

where $A^{\prime}=$ measured amount of EOC (i.e. net release) in samples incubated without SM; $\mathrm{B}=$ EOC incorporated into bacterial biomass; $\mathrm{BR}=$ fraction of assimilated EOC respired. A thus represents the total or gross release of EOC. $\mathrm{P}^{\prime}$ and $\mathrm{P}=$ fixation of $\mathrm{CO}_{2}$ into particles $>0.2 \mu \mathrm{m}$ measured in samples incubated with and without SM, respectively. Rearranging the equations gives:

$$
\begin{aligned}
& \text { (3) } \mathrm{A}-\mathrm{A}^{\prime}=\mathrm{B}+\mathrm{BR}=\mathrm{C} \\
& \text { (4) } \mathrm{P}^{\prime}-\mathrm{P}=\mathrm{B} \\
& \text { (5) } \mathrm{BR}=\mathrm{C}-\mathrm{B}
\end{aligned}
$$

By measuring POC ( $\mathrm{P}$ and $\left.\mathrm{P}^{\prime}\right)$ and $\operatorname{EOC}\left(\mathrm{A}\right.$ and $\mathrm{A}^{\prime}$ ) production in samples incubated with and without SM, gross (C) and net (B) bacterial production can be estimated by assuming algal mixotrophy or heterotrophy to be insignificant (Crawford et al., 1974; Azam and Hodson, 1977) and bacterial release of extracellular products during the incubation to be insignificant compared with the algal release (Dunstall and Nalewajko, 
1975). The percent transport value $(T=C / A \times 100)$ is an estimate of carbon channeled through the bacterial organisms in relation to released EOC.

\section{RESULTS}

\section{Laboratory experiments}

The time varying release of EOC in samples $\pm \mathrm{SM}$ was followed in a series of laboratory experiments. The results from a long- and short-time experiment are presented in Tables 1 and 2.

The long-time experiment carried out before a spring diatom bloom had Diatoma elongatum as dominating taxa (about $25 \%$ of total algal cell volume) whereas the short-time experiment carried out during a spring diatom bloom had Stephanodiscus hantzschii as dominating taxa (about $75 \%$ of total algal cell volume).

In both experiments the release was significantly higher in samples where the bacterial activity was inhibited (Tables 1 and 2). Because the bacteria assimilate EOC simultaneously with the release, the EOC release in samples with an active bacterial population was underestimated by up to $91 \%$ in the first experiment (Table 1). During the diatom bloom the
EOC release was only underestimated by about $40 \%$ (Table 2).

Even if the EOC release is taken into account the autotrophic production (particulate plus dissolved) would be underestimated by up to $15 \%$ because a substantial part of the assimilated EOC was respired (about 20 to $50 \%$, generally increasing with incubation time). The heterotrophic uptake of EOC accounted for 4 to about $30 \%$ of total autotrophic production.

In Fig. 1 production of particulate (POC) and dissolved organic carbon (EOC) for the short-time experiment are presented as cumulative values. The particulate production increased linearly throughout the experiment. Because the POC curve for samples incubated without SM represents the sum of algal POC production $\left(\mathrm{P}^{\prime}\right)$ and bacterial incorporation of EOC into bacterial biomass (B), these samples showed a faster increase in the cumulative values compared with the samples in which the physiological activity of the bacteria were inhibited (Fig. 1).

The released products were predominantly of low molecular weight ( $<900$ Daltons). The low molecular weight products constituted 69 to $100 \%$ before (Table 3) and 39 to $56 \%$ during the spring diatom bloom (Table 4), respectively. Samples incubated with SM on all but one occasion showed a higher proportion of low molecular weight compounds than samples incubated without SM.

Table 1. Cumulative primary production and release of EOC in samples incubated without (') and with streptomycin added. Calculations are explained in text. $\mathrm{P}$ particulate primary production; $\mathrm{P}^{\prime}$ particulate primary production plus net bacterial production; A gross release of EOC: $\mathrm{A}^{\prime}$ net release of EOC; $\mathrm{B}$ bacterial net production; C gross bacterial production; $\mathrm{BR}$ bacterial respiration; T transport of EOC from phytoplankton to bacterioplankton

\begin{tabular}{|c|c|c|c|c|c|c|c|c|c|c|c|c|}
\hline \multirow[t]{2}{*}{ Time } & $\mathrm{P}^{\prime}$ & $P$ & $A^{\prime}$ & A & $A^{\prime} / P^{\prime}+A^{\prime}$ & $A / P+A$ & $\mathrm{C}$ & B & BR & $\mathrm{BR}$ & $\mathrm{T}$ & $\mathrm{C} / \mathrm{P}+\mathrm{A}$ \\
\hline & \multicolumn{4}{|c|}{$\left(\mu \mathrm{gC}^{-1}\right)$} & \multicolumn{2}{|c|}{$(\%)$} & \multicolumn{3}{|c|}{$\left(\mu \mathrm{gC} \mathrm{I}^{-1}\right)$} & \multicolumn{3}{|c|}{$(\%)$} \\
\hline $3 \mathrm{~h}$ & 7.3 & 6.1 & 1.4 & 2.3 & 16.1 & 27.3 & 0.9 & 1.2 & - & - & 39 & 11 \\
\hline $5 \mathrm{hl}$ & 9.8 & 8.3 & 1.6 & 3.6 & 14.0 & 30.1 & 2.0 & 1.5 & 0.5 & 25 & 56 & 17 \\
\hline $17 \mathrm{~h}$ & 32.1 & 27.6 & 2.5 & 12.8 & 7.2 & 31.7 & 10.3 & 4.5 & 5.8 & 56 & 80 & 25 \\
\hline $48 \mathrm{~h}$ & 73.8 & 55.6 & 4.6 & 26.0 & 5.9 & 31.9 & 24.4 & 18.2 & 6.2 & 25 & 94 & 30 \\
\hline $71 \mathrm{~h}$ & 139.0 & 114.0 & 6.0 & 45.5 & 4.0 & 28.5 & 39.5 & 25.0 & 14.5 & 37 & 87 & 25 \\
\hline $138 \mathrm{~h}$ & 284.6 & 251.1 & 18.1 & 79.4 & 2.8 & 24.0 & 71.3 & 33.5 & 37.8 & 53 & 90 & 22 \\
\hline $159 \mathrm{~h}$ & 341.4 & 287.6 & 11.4 & 123.1 & 3.2 & 30.0 & 111.7 & 53.8 & 57.9 & 52 & 91 & 27 \\
\hline
\end{tabular}

Table 2. Cumulative primary production and EOC release in samples incubated with and without streptomycin. See also legend to Table 1

\begin{tabular}{|c|c|c|c|c|c|c|c|c|c|c|c|c|}
\hline \multirow[t]{2}{*}{ Time } & $\mathrm{P}^{\prime}$ & $\mathrm{P}$ & $A^{\prime}$ & A & \multirow{2}{*}{\multicolumn{2}{|c|}{$\frac{A^{\prime} / P^{\prime}+A^{\prime} A / P+A}{(\%)}$}} & $\mathrm{C}$ & B & \multirow[t]{2}{*}{$\mathrm{BR}$} & $\mathrm{BR}$ & $\mathrm{T}$ & $\mathrm{C} / \mathrm{P}+\mathrm{A}$ \\
\hline & \multicolumn{4}{|c|}{$\left(\mu \mathrm{gC}^{-1}\right)$} & & & \multicolumn{2}{|c|}{$\left(\mu \mathrm{gC}^{-1}\right)$} & & \multicolumn{3}{|c|}{$(\%)$} \\
\hline $0.5 \mathrm{~h}$ & 31.05 & 29.30 & 1.78 & 3.02 & 5.4 & 9.3 & 1.24 & 1.75 & - & - & 41 & 4 \\
\hline $1.0 \mathrm{~h}$ & 77.82 & 75.23 & 4.27 & 7.87 & 5.8 & 9.5 & 3.10 & 2.59 & 0.51 & 16 & 39 & 4 \\
\hline $1.5 \mathrm{~h}$ & 121.69 & 117.93 & 9.12 & 14.00 & 7.0 & 10.6 & 4.88 & 3.76 & 1.12 & 23 & 35 & 4 \\
\hline $2.5 \mathrm{~h}$ & 254.00 & 245.11 & 19.01 & 31.82 & 7.0 & 11.5 & 12.81 & 8.92 & 3.89 & 30 & 40 & 5 \\
\hline $3.0 \mathrm{~h}$ & 311.53 & - & 27.48 & - & 8.1 & - & - & - & - & - & - & - \\
\hline $3.5 \mathrm{~h}$ & 365.66 & 353.23 & 29.21 & 48.30 & 7.4 & 12.0 & 19.09 & 12.43 & 6.66 & 35 & 40 & 4 \\
\hline
\end{tabular}




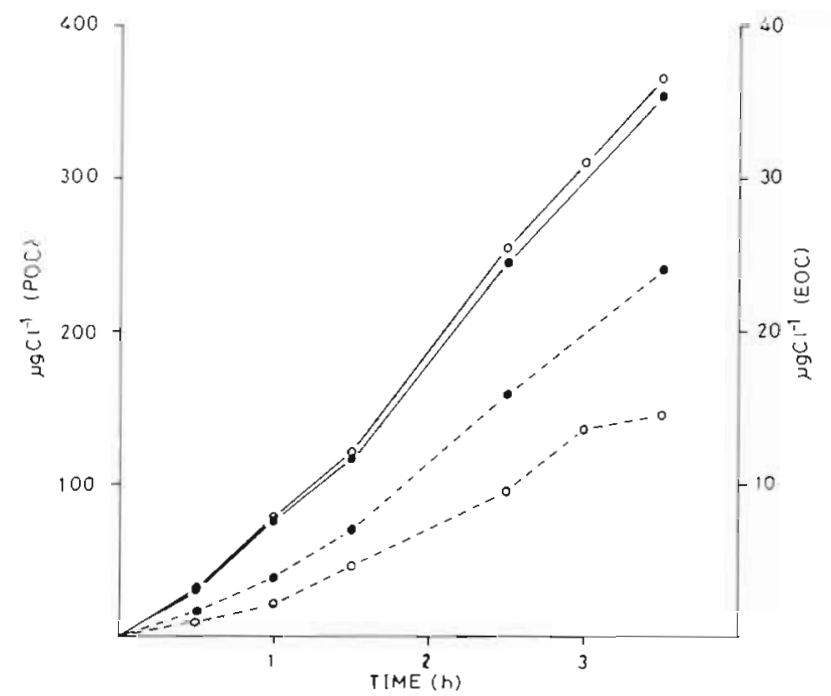

Fig. 1. Cumulative carbon fixation (-) and release of EOC $(---)$ in samples incubated without $(O)$ and with $(\bullet)$ the antibiotic streptomycin

A shift towards an increasing significance of high molecular weight products was generally observed with increasing incubation time. As this increase was observed in samples with as well as in samples without SM, it was concluded that the accumulation of high molecular weight products was not attributable to a bacterial excretion but to an increasing specific activity in the high molecular weight fraction of the extracellular pool of EOC.

While products of $\mathrm{MW}>2.500$ dominated the high molecular fraction before the bloom (Table 3), inter-

Table 3. Molecular weight distribution of EOC as a function of time. + samples incubated with $\mathrm{SM}_{i}$ - samples incubated without SM. Values represent per cent EOC released in various molecular weight fractions

\begin{tabular}{|rrrrrrr}
\hline $\begin{array}{l}\text { Molecular weight } \\
\text { (Daltons) }\end{array}$ & \multicolumn{2}{c}{$5 \mathrm{~h}$} & \multicolumn{2}{c}{$48 \mathrm{~h}$} & \multicolumn{2}{c|}{$138 \mathrm{~h}$} \\
\hline$>2.500$ & 0 & 0 & 20 & 18 & 19 & 26 \\
$<2.500>900$ & 0 & 0 & 2 & 2 & 4 & 5 \\
$<900$ & 100 & 100 & 78 & 80 & 77 & 69 \\
\hline
\end{tabular}

Table 4. Molecular weight distribution of EOC as a fumction of time. + samples incubated with $\mathrm{SM}_{i}$ - samples incubaled without SM. Values represent per cent EOC released in various molecular weight fractions

\begin{tabular}{lllllllll}
$\begin{array}{c}\text { Molecular weight } \\
\text { (Daltons) }\end{array}$ & $+1.5 \mathrm{~h}$ & \multicolumn{2}{c}{$2.5 \mathrm{~h}$} & \multicolumn{2}{c}{$3.5 \mathrm{~h}$} \\
\hline & + & & + & - & + & - \\
\hline 2.500 & 12 & 23 & 22 & 24 & 14 & 23 \\
$<2.500>900$ & 32 & 26 & 29 & 33 & 36 & 38 \\
$<900$ & 56 & 51 & 49 & 43 & 50 & 39 \\
\hline
\end{tabular}

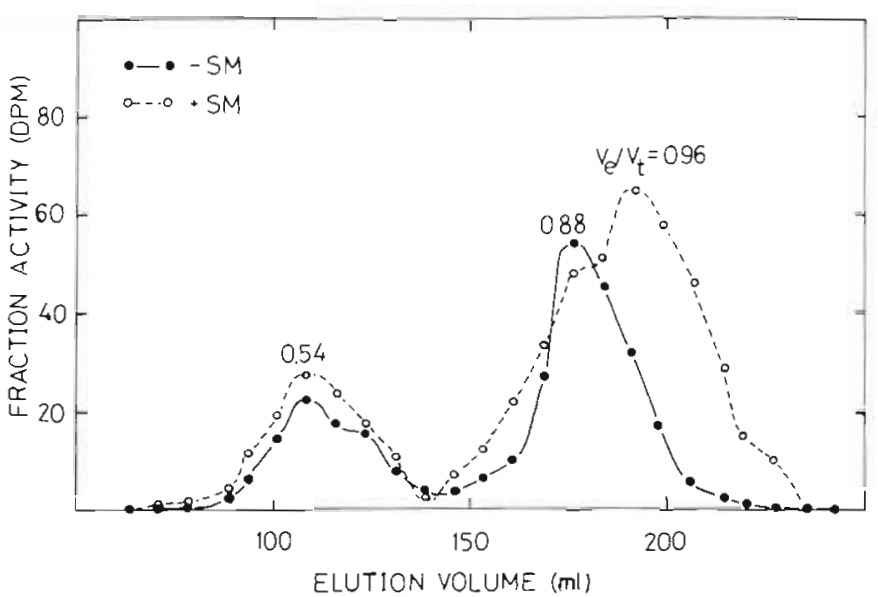

Fig. 2. Sephadex gel-fractionation after $138 \mathrm{~h}$ of incubation

mediary products of $\mathrm{MW}<2.500>900$ were of equivocally importance during the bloom (Table 4). An example of a gel-chromatogram is presented in Fig. 2.

The heterotrophic utilization of EOC products in different molecular weight fractions $(>2.500,<2.500$ $>900,<900$ Daltons) was estimated by subtracting the integrated area under the elution curves from both sample-types (Fig. 2). A large part (58 to $100 \%$ ) of the assimilated products consisted of small molecular weight products. As a consequence of this bacterial selectivity the remaining EOC pool consisted of a greater percentage of products with a $M W>900$.

\section{In situ experiments}

The diel primary production, EOC release and transport of newly photosynthetically fixed carbon through the bacteria was followed on two days during the collapse of a spring diatom bloom.

Stephanodiscus hantzschii (ca. $75 \%$ of total algal cell volume) and small green flagellates (ca. $10 \%$ of total algal cell volume) dominated the phytoplankton. Because the data from both days followed the same general pattern, only results from one of the days are presented below

In contrast to the laboratory experiments the bacterial net production (B) was always several times larger than bacterial gross production (C) resulting in negative respiration values (Table 5). Unfortunately a separate control of the effect of streptomycin on algal metabolism was not included in the in situ experiments. The negative BR values can, however, probably be explained by an inhibition of the algal metabolism. Hence, the values for bacterial uptake (C) must be taken as minimum values. A close positive correlation between the photosynthetic rate and release rate of EOC could be demonstrated $(r=0.77, p<0.001)$. 
Table 5. Vertical distribution of primary production and release of EOC from sunrise to sunset under the collapse of a spring diatom bloom in the estuary Randers Fjord. See also legend to Table 1

\begin{tabular}{|c|c|c|c|c|c|c|c|c|c|c|c|c|}
\hline \multirow{2}{*}{$\begin{array}{l}\text { Time } \\
05.30-\end{array}$} & \multirow{2}{*}{$\begin{array}{c}\text { Depth } \\
\text { (m) } \\
0\end{array}$} & \multicolumn{4}{|c|}{$\begin{array}{l}\mathrm{P} \quad \mathrm{A}^{\prime} \\
\left(\mu \mathrm{gC} \mathrm{I}^{-1}\right)\end{array}$} & \multicolumn{2}{|c|}{$\begin{array}{c}A^{\prime} / P^{\prime}+A^{\prime} A / P+A \\
(\%)\end{array}$} & \multicolumn{3}{|c|}{ C $\quad \begin{array}{c}\text { B } \\
\quad\left(\mu g \mathrm{C} \mathrm{l}^{-1}\right)\end{array}$} & \multicolumn{2}{|c|}{$\begin{array}{l}\mathrm{C} / \mathrm{P}+\mathrm{A} \\
(\%)\end{array}$} \\
\hline & & 51.60 & 41.52 & 4.68 & 7.11 & 8 & 15 & 2.43 & 10.08 & - & 34 & 5 \\
\hline \multirow[t]{2}{*}{08.30} & 1 & 38.80 & 30.42 & 4.57 & 7.22 & 11 & 19 & 2.65 & 8.38 & - & 37 & 7 \\
\hline & 2 & 20.60 & 16.60 & 3.41 & 6.72 & 14 & 29 & 3.31 & 4.00 & - & 50 & 14 \\
\hline $08.30-$ & 0 & 51.88 & 40.04 & 2.56 & 4.57 & 5 & 10 & 2.01 & 11.84 & - & 44 & 4 \\
\hline \multirow[t]{2}{*}{10.30} & 1 & 44.62 & 35.05 & 2.07 & 3.97 & 5 & 10 & 1.90 & 9.57 & - & 48 & 5 \\
\hline & 2 & 31.79 & 25.12 & - & - & - & - & - & 6.67 & - & - & - \\
\hline $10.30-$ & 0 & 77.97 & 60.82 & 4.73 & 7.74 & 6 & 11 & 3.01 & 17.15 & - & 39 & 4 \\
\hline \multirow[t]{2}{*}{12.30} & 1 & 64.64 & 53.16 & 4.29 & 7.43 & 6 & 12 & 3.14 & 11.48 & - & 42 & 5 \\
\hline & 2 & 51.36 & 43.12 & 3.25 & 6.10 & 6 & 12 & 2.85 & 8.24 & - & 47 & 6 \\
\hline $12.30-$ & 0 & 68.11 & 52.22 & 4.36 & 6.22 & 6 & 11 & 1.86 & 15.89 & - & 30 & 3 \\
\hline \multirow[t]{2}{*}{14.30} & 1 & 56.65 & 43.89 & 4.20 & 7.10 & 7 & 14 & 2.90 & 12.76 & - & 41 & 6 \\
\hline & 2 & 43.72 & 34.71 & 3.72 & 6.04 & 8 & 15 & 2.32 & 9.01 & - & 38 & 6 \\
\hline $14.30-$ & 0 & 43.14 & 32.88 & 3.87 & 6.07 & 8 & 16 & 2.20 & 10.26 & - & 36 & 6 \\
\hline \multirow[t]{2}{*}{16.30} & 1 & 33.39 & 24.57 & 4.05 & 5.83 & 11 & 19 & 1.78 & 8.82 & - & 31 & 6 \\
\hline & 2 & 18.13 & 12.64 & 3.18 & 4.57 & 15 & 27 & 1.39 & 5.49 & - & 30 & 8 \\
\hline $16.30-$ & 0 & 28.61 & 20.04 & 4.52 & 5.25 & 14 & 21 & 0.73 & 8.57 & - & 14 & 3 \\
\hline \multirow[t]{2}{*}{19.30} & 1 & 19.41 & 15.53 & 3.23 & 4.38 & 14 & 22 & 1.15 & 3.88 & - & 26 & 6 \\
\hline & 2 & 10.55 & 8.32 & 2.09 & 3.27 & 17 & 28 & 1.18 & 2.23 & - & 36 & 10 \\
\hline$\Sigma$ & 0 & 321.31 & 247.52 & 24.72 & 36.95 & 7 & 13 & 12.23 & 73.79 & - & 33 & 4.3 \\
\hline $05.30-$ & 1 & 257.51 & 202.61 & 22.41 & 35.93 & 8 & 15 & 13.52 & 54.90 & - & 38 & 5.7 \\
\hline 19.30 & 2 & 176.15 & 140.51 & 17.55 & 29.46 & 9 & 17 & 11.91 & 35.64 & - & 40 & 7.0 \\
\hline
\end{tabular}

Of the released products a substantial part $(\mathrm{C}=$ $33-40 \%$ ) were assimilated by the bacteria. The assimilation generally increased with depth. The bacterial assimilation rates were linked to the release rates $(r=$ $0.75, \mathrm{p}<0.001)$.

Calculated on a diel basis the gross release (A) accounted for 13,15 and $17 \%$ of total autotrophic production $(\mathrm{P}+\mathrm{A})$ at the surface, $1 \mathrm{~m}$ depth and at the bottom, respectively.

About one third of the released EOC during the $14 \mathrm{~h}$ light period was assimilated by the microheterotrophs, making up 4, 6 and $7 \%$ of total algal production at the surface, $1 \mathrm{~m}$ depth and at the bottom. Assuming zero release from the phytoplankton at night, about 60 to $70 \%$ of the released products would be assimilated throughout a 24 hour period. Thus, on a diurnal basis approximately one third of the released carbon accumulated.

The molecular weight composition of the released products showed only minor variation through the day. Daily average values for surface samples are presented in Table 6.

As was the case in the laboratory experiments a dominating fraction $(60 \%)$ consisted of low molecular weight products $<900$ Daltons. The intermediate $(<2500>900$ Daltons) and high ( $>2500$ Daltons) molecular weight fractions represented 23 and $17 \%$ of total release. In contrast to the laboratory experiments
Table 6. Daily average molecular weight distribution of EOC from surface water under the collapse of a spring diatom bloom in the estuary Randers Fjord. Samples incubated with $(+)$ and without $(-)$ streptomycin

\begin{tabular}{|c|c|c|c|}
\hline & \multicolumn{3}{|c|}{ Molecular weight (Daltons) } \\
\hline & $>2500$ & $<2500>900$ & $<900$ \\
\hline+ & 17 & 23 & 60 \\
\hline- & 18 & 22 & 60 \\
\hline
\end{tabular}

the relative distribution of EOC on MW fractions were almost identical between samples incubated with and without SM (Table 6). As shown in Fig. 3, which represents a typical elution diagram from the in situ experiments, this similarity was a consequence of the chosen division of the molecular weight spectrum while doing the integration.

The released products at $V_{\mathrm{e}} / \mathrm{V}_{\mathrm{t}}=0.99,0.66$ and 0.51 represent molecules with a MW of $<900,>2500$ $<3000$ and $>4000<6000$ Daltons, respectively. The peak at $\mathrm{V}_{\mathrm{e}} / \mathrm{V}_{\mathrm{t}}=0.40$ is molecules eluted in the void volume (>10000 Daltons) (Fig. 3).

A dominating amount (about $57 \%$ ) of the extracellulary carbon assimilated by the bacteria consisted of substances $<900$ Daltons. Intermediary molecular weight $(<2500>900$ Daltons) and high molecular weight ( $>2500$ Daltons) products made out about 26 and $17 \%$ of the total assimilation. 


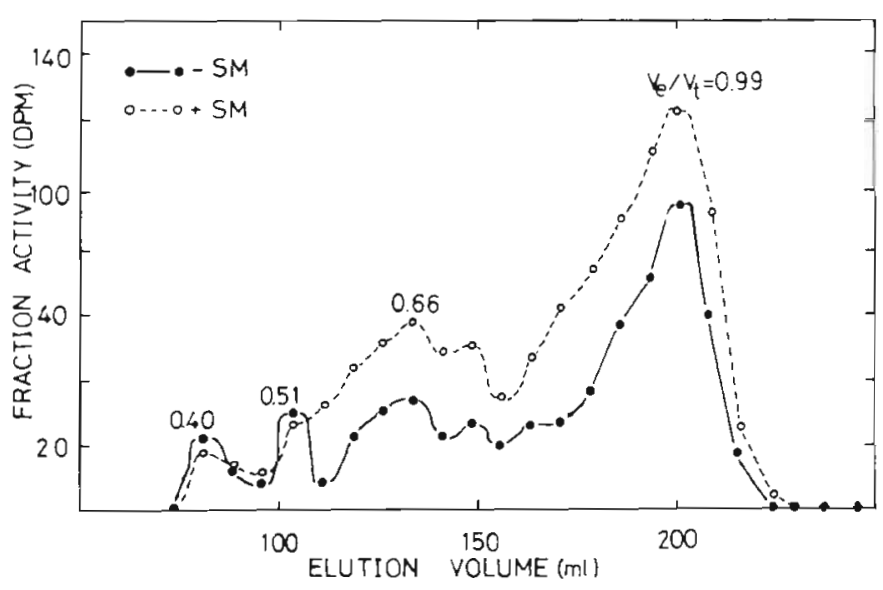

Fig. 3. Sephadex gel-fractionation of EOC from field experiment

\section{DISCUSSION}

In the present study it was assumed that glucose active bacteria exhibited an SM sensitivity representative of the total metabolic active bacterial population. If so, an SM concentration of 25 to $30 \mu \mathrm{g} \mathrm{ml} \mathrm{ml}^{-1}$ was sufficient to inhibit bacterial assimilation of EOC by more than $90 \%$.

Schleyer (1981) used a heterotrophic potential technique to measure the assimilation of a labeled algal extract and glucose in samples with and without antibiotics. Depending upon the antibiotics used, Schleyer (1981) found the inhibition of glucose assimilation to be 3 to $37 \%$ larger than the inhibition of bacterial assimilation of an algal extract (calculated from Table 7). Thus, in the present study where the decrease in glucose assimilation was used to measure inhibition, the measured release rates in samples incubated with SM may probably be taken as minimum values.

Because, streptomycin specifically inhibits protein synthesis on the 70-S ribosome and misreading of the genetic code (Jacoby and Gorini, 1967), SM may also affect algal organellar protein synthesis. The concentrations required to significantly affect algal mitochondria and chloroplast are, however, considerably higher than those necessary to inhibit bacterial activity (Stanier et al., 1977).

Thus, it should be possible to block bacterial activity without affecting the photosynthetic carbon fixation significantly (Berman, 1975; Iturriaga and Hoppe, 1977). However, photosynthetic rates may be depressed at antibiotic concentrations not sufficient to inhibit the bacterial assimilation effectively. Derenbach and Williams (1974) for example observed an inhibition of the primary production from 20 to $80 \%$ varying with samples and type of inhibitor. Furthermore, the time of contact between algae and antibiotics may be important (Chrost, 1978).

In the laboratory experiments no toxic effect of SM on algal metabolism was observed as judged from the time course of carbon fixation (Tables 1 and 2; Fig. 1). Even after a period of more than $6 \mathrm{~d}$, the algal EOC production in samples incubated with SM paralleled those of the blanks (Table 1).

The release of photosynthetically derived carbon by phytoplankton is a normal physiological process (Maque et al, 1980). In addition the quantity of material released seems to be regulated by processes affecting the overall photosynthetic rate (Smith et al., 1977). Thus, if SM induces a malfunction of algal organellar synthesis it will be anticipated to be reflected in the quantity of EOC released. Although the time course experiments revealed a different pattern of EOC release such an effect on algal release could not be delineated from the data (Tables 1 and 2).

At the very beginning of both laboratory experiments net bacterial production (B) exceeded gross bacterial production (C) (Tables 1 and 2). The calculated respirations values $(B R)$ therefore were negative. From Equation $5\left(B R=\left(A-A^{\prime}\right)-\left(P^{\prime}-P\right)\right.$ it follows that negative respiration values may result if the release in samples incubated with SM (A) are underestimated and/or the autotrophic fixation of carbon dioxide into algal biomass (P) are overestimated. An underestimation of A may either be a consequence of ineffective bacterial inhibition or SM depressed algal organellar synthesis.

Overestimation of $\mathrm{P}$ may occur as a result of incomplete bacterial inhibition or inhibition of autotrophic carbon dioxide fixation. Both situations would tend to results in negative respiration values.

Because natural water represents a complex microbial system a bacterial and algal response to antibiotics cannot easily be separated. Depending upon bacterial growth efficiency the ratio $P+A / P^{\prime}+A^{\prime}$ will attain values greater than or equal to unity as long as the algal inhibition does not exceed bacterial respiration.

If the antibiotic inhibits algal metabolism to a significant extent can thus be read from the ratio values. As $\mathrm{P}+\mathrm{A} / \mathrm{P}^{\prime}+\mathrm{A}^{\prime}$ increased during the experiments and the CV varied between 2 and $5 \%$ it is concluded that no significant inhibition of algal metabolism occurred during the laboratory experiments. In the in situ experiments the ratios were significantly less than unity (0.71-0.97) (Table 5) suggesting an inhibition of the algal production with at least 3 to $29 \%$.

The difference in algal sensitivity observed between the laboratory experiments and the in situ experiments seemed not related to algal species. Both in the short- 
time laboratory experiment and in the in situ experiment Stephanodiscus hantzschii accounted for approximately $75 \%$ of total algal cell volume. Therefore, the increase in algal sensitivity to SM probably was related to the physiological state of the algae. Senescent phytoplanktons might possess a reduced resistance to SM compared with actively metabolizing and growing algae.

\section{Laboratory experiments}

The results for laboratory experiments support the findings by Gocke (1970) and Nalewajko et al. (1976) that bacteria may modify the kinetics of extracellular release significantly

In the long-time experiment the difference in PER between parallel samples increased with incubation time as a result of an initial lag in bacterial assimilation of algal EOC (Nalewajko et al., 1976). After a lag period of several hours the assimilation rate increased significantly allowing no further accumulation (Table 1).

Calculation of release is often made under the assumption that the specific activity of the intracellular pool of EOC has the same specific activity as the inorganic carbon pool (Nalewajko, 1977). A comparison of the molecular weight distribution of the released EOC after $5 \mathrm{~h}$ and $48 \mathrm{~h}$ of incubation (Table 3 ) shows that the assumption of a fast isotopic equilibrium in the EOC products can lead to serious underestimation of the release.

In the short-time experiment no lag was observed. The increase in PER in samples with SM may reflect release from an intracellular pool not in isotopic equilibrium. However, as no significant increase of high molecular weight products was observed (Table 4) it is concluded that the increase in PER was caused by a release of EOC to an extracellular pool of increasing specific activity (Coveney, 1982). Due to bacterial assimilation of the released products in samples with an intact bacterial population the time course followed a nonlinear release pattern (Lancelot, 1979).

The percent transport value ( $T$ ), which is an estimate of carbon flux through the bacterial organisms in relation to released EOC, was 39 to $91 \%$ and ca. $40 \%$ in the long- and short-time experiments, respectively. Expressed in another way: the bacteria removed 39 to $91 \%$ of the total amount of released matter per hour in the two laboratory experiments. With a similar procedure, but using the antibiotic gentamycin, Chrost (1978) measured $\mathrm{T}$ values of 21 to $83 \%$ (calculated from his Tables IV and V). Similar results (25 to $80 \%$ ) were obtained by Coveney (1982) in Lake Bysjön, while Cole et al. (1982) in Mirror Lake found $T$ to average 38 and $43 \%$ for short-time intervals and $24 \mathrm{~h}$ incubations, respectively.

A substantial and with time increasing part of the released algal EOC was respired. The estimated values of 16 to $52 \%$ agree well with the results of Bell and Sakshaug (1980). By a kinetic approach they measured bacterial respiration of EOC from axenic cultures of Chaetoceros affinis and Skelotonema costatum to constitute 5 to $27 \%$ and 30 to $35 \%$, respectively. On a diel basis Cole et al. (1982) calculated bacterial respiration to account for $56 \%$ of total bacterial utilization of EOC in Mirror Lake.

Wiebe and Smith (1977) reported that $95 \%$ of the released extracellular products by marine phytoplankton consisted of molecules with an MW less than 3500. Mague et al. (1980) found small molecules to dominate the extracellular pool of EOC products.

Søndergaard and Schierup (1982), during a diatom bloom in Lake Mossø, found products $<700$ Daltons to be dominating ( 70 to $77 \%$ ). Only after the biomass maxima and during the stationary phase were high molecular weight products ( $>10000$ Daltons) released in appreciable amount $(\sim 20 \%)$.

In the present study low molecular weight products ( $<900$ Daltons) dominated the release (50 to $78 \%$ ) while products of $\mathrm{MW}>2500$ accounted for only 12 to $26 \%$ (Tables 3 and 4 ).

Products with an intermediary MW $1<2500>900)$ were liberated to a different extent in the 2 experiments. In the long-time experiments where Diatoma elongatum dominated the phytoplankton intermediary compounds of $<2500>900$ Daltons constituted only 0 to $4 \%$ of total released EOC. In the short-time experiment with Stephanodiscus hantzschii as dominating taxa this fraction constituted 29 to $36 \%$ of released EOC.

Different algal species release specific products (Hellebust, 1965; Watt, 1966; Nalewajko and Lean, 1972). Therefore the observed change in the molecular weight distribution of EOC may be a result of specific release.

Release of extracellular dissolved organic carbon by bacteria has been reported (Nalewajko and Lean, 1972; Dunstall and Nalewajko, 1975; Iturriaga and Zsolnay, 1981). Although especially high molecular weight products seem to be released (Wilkenson, 1958; Nalewajko and Lean, 1972), low molecular weight substances may also be released (Nalewajko, 1977). However, incubations of about $24 \mathrm{~h}$ are necessary before EOC of bacterial origin can be found in significant amounts (Dunstall and Nalewajko, 1975).

Though the composition of EOC is difficult to approach accurately in samples without SM, because algal release and bacterial assimilation/release may occur simultaneously, bacterial EOC was not found to 
be released in appreciable amounts in the laboratory experiments. After $138 \mathrm{~h}$, however, low molecular weight products, probably of bacterial origin, appeared at $V_{\mathrm{e}} / V_{1}=0.88$ (Fig. 2). Therefore, calculations of preferential assimilated compounds in different molecular weight fractions are rough estimates only.

Small molecules < 900 Daltons were assimilated to a greater extent than products of higher molecular weight. Thus, 58 to $100 \%$ of gross bacterial production was due to assimilation of small molecules. Similar results were obtained by Nalewajko et al. (1976) with EOC products from Ananaena flos-aqua. They found a substantial bacterial utilization of low molecular weight products, while only small amounts of larger molecules were assimilated. Also, Iturriaga (1981) found low molecular weight products $(<500$ Daltons) from a natural phytoplankton assemblage to be assimilated at a higher rate. After $12 \mathrm{~h}$ of incubation $46 \%$ of the assimilated EOC consisted of small molecules less than 500 Daltons (calculated from Fig. 2).

\section{In situ experiment}

The high correlation as found in the present study between particulate carbon fixation and EOC production has been demonstrated previously (Anderson and Zeutschel, 1970; Berman and Holm-Hansen, 1974; Smith et al., 1977). Similarly, a relationship between bacterial activity and the photosynthetic rate has been demonstrated (Allen, 1969; Hobbie et al., 1972; Wright, 1973; Thompson and Hamilton, 1973; Derenbach and Williams, 1974) suggesting that EOC may exert major stimulatory effects on bacterial populations (Bell et al., 1974; Meffert and Overbeck, 1979).

In Randers Fjord a close correlation between release rate and assimilation rate was found $(r=0.75$, $\mathrm{p}<0.001$ ), indicating that EOC serves as an important carbon source for the indigeneous bacterial population.

The bacterial assimilation rate amounted to 14 to $50 \%$ of the release rate (A) with a daily average value of 33,38 and $40 \%$ for surface, $1 \mathrm{~m}$ depth and bottom samples, respectively.

In a eutrophic upwelling area, Smith et al. (1977) by means of a carbon mass flux model calculated bacterial assimilation to proceed at a rate of ca. 18 to $33 \%$ of the release rate. Likewise, in the southern North Sea, Lancelot (1979) - using a mathematical model - calculated a bacterial assimilation rate of 15 to $39 \%$ of the release rate. In Lake Bysjön Coveney (1982) found a per cent transport from 28 to $80 \%$ after $4 \mathrm{~h}$ incubation. Similar results (30 to $70 \%$ ) were obtained by Riemann et al. (1982) during a diatom bloom in Lake Mossø.
These results suggest that algal EOC products are highly assimilable and that bacterial assimilation may proceed at a rate comparable to the release rate. However, as most of the above cited results are net values, i. e. no correction for bacterial respiration has been made, assimilation rates may in some circumstances equal the rate of release.

Assuming zero or a much reduced release rate in the dark period (Mague et al., 1980) and uptake of EOC continuing at similar rates at night, bacterial production during a $24 \mathrm{~h}$ period equals 19 to $24 \mathrm{\mu gCl}^{-1}$. Thus ca. 10 to $13 \mu \mathrm{gC}^{-1}$ or about one third of the release in the light period was still unmetabolized at the end of a 24 h period.

As most of the EOC material consisted of molecules $<900$ Daltons, which generally is found to be labile (Chrost, 1981; Iturriaga, 1981), a diurnal accumulation of EOC products was unexpected. Although long turnover times and substantial accumulation of EOC products have been reported (Bell and Sakshaug, 1980) it is not generally the rule (Riemann et al., 1982). However, if a substantial part of the planktonic bacteria (predominantly of limnic and terrigeneous origin, own unpubl. data) are non-viable or metabolically inactive because of salt stress (Rheinheimer, 1968) an accumulation of EOC products may occur.

This interpretation is supported by the observation that a large fraction $(\sim 30 \%)$ of total AODC-counts were green fluorescent cells (own unpubl. data) which represent inactive bacterial cells (Hobbie et al., 1977).

Although the bacterial uptake of EOC (C) did not constitute more than 3 to $14 \%$ (average 4 to $7 \%$ ) of the total primary production, $\mathrm{C}$ can in situations with a high per cent release constitute a substantial part of total algal production (Table 1). Furthermore, in the ensuing dark period the heterotrophic population continues to metabolize, raising the value of $C$ (Derenbach and Williams, 1974).

While release of EOC may not be an important loss of carbon for the phytoplankton, i.e. low per cent release and consequently a low ratio of $\mathrm{C}$ to total primary production, it may be an important carbon source for the bacteria (Coveney, 1982). This is supported by the results of Riemann and Søndergaard (in press). These authors calculated a per cent release of ca. 7 and $11 \%, C$ to constitute ca. 5 and $8 \%$ of total primary production in Frederiksborg Slotssø and Lake Mossø, respectively. By estimating total bacterial production by the method of frequency of dividing cells, they found EOC compounds to constitute 63 and $70 \%$ of total bacterial production (calculated from Table 1).

The present investigation has shown that SM can be used as a potent inhibitor of the physiological activity of bacteria. Using ${ }^{14} \mathrm{C}$-glucose uptake in parallel samples \pm SM to estimate bacterial inhibition, an almost 
complete inactivation $(\sim 90 \%)$ of bacterial activity was achieved. This requires of course the assumption that glucose active bacteria dominate the actively metabolishing bacterioplankton and that glucose uptake is inhibited to a similar extent as EOC assimilation. Both assumptions do not always seem fulfilled (Schleyer, 1981; Riemann et al., 1982).

During the laboratory experiments no effects of SM on algal production were observed. During the field experiments algal production was inhibited by at least 3 to $29 \%$. As judged from the gel-chromatograms (Fig. 3) the inhibition resulted not, however, in a release of different products, but only in a lowering of photosynthesis and release rates.

The possibility of a slight inhibition of the phytoplankton during the laboratory experiments, however, exists as it is impossible with the present method to detect a small decrease in algal production in a sample with simultaneously running autotrophic and heterotrophic processes. As both incomplete bacterial inhibition and an inhibition of algal metabolism tend to underestimate the gross release, the results obtained in the present investigation have to be considered minimum values. Therefore, the presented results support further evidence to the general view that algal extracellular products mainly consist of small molecules (<900 Daltons) (Mague et al., 1980; Chrost, 1981; Iturriaga, 1981; Sondergaard and Schierup, 1982) which are assimilated and respired with high efficiency (Iturriaga, 1981; Coveney, 1982; Riemann et al., 1982).

Acknowledgement. I thank Dr. M. Søndergaard for helpful suggestions and constructive criticism of the manuscript.

\section{LITERATURE CITED}

Allen, H. L. (1969). Chemo-organotrophic utilization of dissolved organic compounds by planktonic algae and bacteria in a pond. Int. Revue ges. Hydrobiol. 54: 1-33

Anderson, G. C., Zeutschel, R. P. (1970). Release of dissolved organic matter by marine phytoplankton in coastal and offshore areas of the North-East Pacific Ocean. Limnol. Oceanogr. 15: 402-407

Azam, F., Hodson, R. E. (1977). Size distribution and activity of marine michroheterotrophs. Limnol. Oceanogr 22: 492-501

Bell, W. H., Lang, J, M., Mitchel, R. (1974). Selective stimulation of marine bacteria by algal extracellular products. Limnol. Oceanogr. 19: 833-839

Bell, W. H., Sakshaug, E. (1980). Bacterial utilization of algal extracellular products. 2. A kinetic study of natural populations. Limnol. Oceanogr. 25: 1021-1033

Berman, T. (1975). Size fractionation of natural aquatic populations associated with autotrophic and heterotrophic carbon uptake. Mar. Biol. 33: 215-220

Berman, T., Holm-Hansen, O. (1974). Release of photoassimilated carbon as dissolved organic matter by marine phytoplankton. Mar. Biol. 28: 305-310
Chrost, R. J. (1978). The estimation of extracellular release by phytoplankton and heterotrophic activity of aquatic bacteria. Acta Microbiologica Polonica 27: 139-146

Chrost, R. J. (1981). The composition and bacterial utilization of DOC released by phytoplankton. Kieler Meeresforsch. Sonderh. 5: 325-332

Cole, J. J., Likens, G. E., Strayer, D. L. (1982). Photosynthetically - produced dissolved organic carbon: an important carbon source for planktonic bacteria. Limnol. Oceanogr., in press

Coveney, M. F. (1982). Bacterial uptake of photosynthetic carbon from freshwater phytoplankton. Oikos 38: 8-20

Crawford, C. C., Hobbie, J. E., Webb, K. L. (1974). The utilization of dissolved free amino acids by estuarine microorganisms. Ecology 55: 551-563

Derenbach, J. B., Williams, P. J. LeB. (1974). Autotrophic and bacterial production: fractionation of plankton populations by differential filtration of samples from the English Channel. Mar. Biol. 25: 263-269

Dunstall, T. G., Nalewajko, C. (1974). Extracellular release in planktonic bacteria. Verh. int. Verein. theor. angew. Limnol. 19: 2643-2649

Gargas, E. (ed.) 1975. A manual for phytoplankton primary production studies in the Baltic. Publs. Baltic Mar. Biologist 2

Gocke, K. (1970). Untersuchungen über Abgabe und Aufnahme von Aminosäuren und Polypeptiden durch Planktonorganismen. Arch. Hydrobiol. 67: 285-367

Hellebust, J. A. (1965). Excretion of some organic compounds by marine phytoplankton. Limnol. Oceanogr. 10: 192-206

Herbland, A. (1975). Utilisation par la flore heterotrophe de la matiére organique naturelle dans l'eau de mer. J. exp. mar. Biol. Ecol.19: 19-31

Hobbie, J. E., Daley, R. J., Jasper, S. (1977). Use of nucleopore filters for counting bacteria by fluorescence microscopy. Appl. environ. Microbiol. 33: 1225-1228

Hobbie, J. E., Holm-Hansen, O., Packard, T T., Pomeroy, L. R., Sheldon, R. W., Thomas, J. P., Wiebe, W. J. (1972). A study of the distribution and activity of microorganisms in ocean water. Limnol. Oceanogr. 17: 544-555

Iturriaga, R. (1981). Phytoplankton photoassimilated extracellular products: heterotrophic utilization in marine environments. Kieler Meeresforsch. Sonderh. 5: 318-324

Iturriaga, R., Hoppe, H. G. (1977). Observations of heterotrophic activity on photoassimilated organic matter. Mar. Biol. 40: 101-108

Iturriaga, R., Zsolnay, A. (1981). Transformation of some dissolved organic compounds by a natural heterotrophic population. Mar. Biol. 62: 125-129

Jacoby, G. A., Gorini, L. (1967). The effects of streptomycin and other aminoglycoside antibiotics on protein synthesis. In: Gottlieb, D., Shaw, P. D. (eds.) Antibiotics, Vol. 1, Mechanism of action. Springer Verlag, Heidelberg, p. 726-747

Lancelot, C. (1979). Gross excretion rates of natural marine phytoplankton and heterotrophic uptake of excreted products in the Southern North Sea, as determined by shortterm kinetics. Mar. Ecol. Prog. Ser. 1: 179-186

Larsson, U., Hagström, §. (1979). Phytoplankton exudate release as an energy source for the growth of pelagic bacteria. Mar. Biol. 52: 199-206

Larsson, U., Hagström, §. (1982). Fractionated phytoplankton primary production, exudate release, and bacterial production in a Baltic eutrophication gradient. Mar. Biol. 67: $57-70$

Mague, T. H., Friberg, E., Hughes, D. J., Morris, I. (1980). Extracellular release of carbon by marine phytoplankton: a physiological approach. Limnol. Oceanogr. 25: 262-279 
Meffert, M. E., Overbeck, J. (1979). Regulation of bacterial growth by algal release products. Arch. Hydrobiol. 87 : 118-121

Morris, I., Yentsch, C. M., Yentsch, C. S. (1971). Relationship between light carbon dioxide fixation and dark carbon dioxide fixation by marine algae. Limnol. Oceanogr. 16: 854-858

Nalewajko, C. (1977). Extracellular release in freshwater algae and bacteria: extracellular products of algae as a source of carbon for heterotrophs. In: Cairns, J. (ed) Aquatic microbial communities. Garland Publishing, Inc., New York, London, p. 589-624

Nalewajko, D., Dunstall, T., Shear, H. (1976). Kinetics of extracellular release in axenic algae and in mixed algal bacteria cultures: significance in estimation of total (gross) phytoplankton excretion rates. J. Phycol. 12: 1-5

Nalewajko, C., Lean, D. R. S. (1972). Growth and excretion in planktonic algae and bacteria. J. Phycol. 8: 361-366

Pharmacia Corporation (1977). Sephadex gel filtration in theory and practice. Pharmacia Corp., Uppsala, Sweden

Rheinheimer, G. (1968). Beobachtungen über den Einfluß von Salzgehaltsschwankungen auf die Bakterienflora der westlichen Ostsee. Sarsia 34: 253-262

Riemann, B., Søndergaard, M. (in press). Bacterial growth in relation to phytoplankton primary production and extracellular release of organic carbon. In: Hobbie, $T$., Williams, P. J. LeB. (eds.) Heterotrophic activity in the sea. Plenum Press, London

Riemann, B., Søndergaard, M., Schierup, H.-H., Bosselmann, S., Christensen, G., Hansen, J. \& Nielsen, B. (1982). Carbon metabolism during a diatom bloom in eutrophic Lake Mossø. Int. Revue ges. Hydrobiol. Hydrogr. 67: 145-185

Schleyer, M. H. (1981). Microorganisms and detritus in the water column of a subtidal reef of Natal. Mar. Ecol. Prog. Ser $4: 307-320$

Smith, W. O., Barber, R. T., Huntsman, S., (1977). Primary production off the coast of northwest Africa: excretion of dissolved organic matter and its heterotrophic uptake. Deep Sea Res. 24: 35-47

Stanier, R. Y., Adelberg, E. A., Ingraham, J. L. (1977). GeneraI microbiology. The MacMillan Press LTD, London

Sondergaard, M. (1980). Adsorption of inorganic carbon - 14 to polyethylene scintillation vials - a possible source of error in measures of extracellular release of organic carbon. Arch. Hydrobiol. 90: 362-366

Søndergaard, M. Schierup, H.-H. (1982). Release of extracellular organic carbon during a diatom bloom in Lake Mosse: molecular weight fractionation. Freshwat. Biol. 12: $313-320$

Thompson, B. M., Hamilton, R. D. (1973). Heterotrophic utilization of sucrose in an artificially enriched lake. J. Fish. Res. Bd Can. 30: 1547-1552

Watt, W. D. (1966). Release of dissolved organic material from the cells of phytoplankton populations. Proc. R. Soc. B. 164: $521-551$

Wiebe, W. J., Smith, D. F. (1977). Direct measurement of dissolved organic carbon release by phytoplankton and incorporation by microheterotrophs. Mar. Biol. 42: 213-223

Wilkenson, J. F. (1958). The extracellular polysaccharides of bacteria. Bacteriol. Rev, 22: 46-73

Wright, R. T. (1973). Some difficulties in using ${ }^{14} \mathrm{C}$-organic solutes to measure heterotrophic bacterial activity. In: Stevenson, L. H., Colwell, R. R. (eds.) Estuarine microbial Ecology. University of South Carolina Press, Columbia, p. $199-217$

This paper was submitted to the editor; it was accepted for printing on October 19, 1982 